\title{
Mapping and Estimation of Chemical Concentrations in Surface Soils Using LANDSAT TM Satellite Imagery
}

\author{
B.B. Maruthi Sridhar and Robert K. Vincent \\ Department of Geology, Bowling Green State University, Bowling Green, OH 43403 \\ United States
}

\section{Introduction}

Application of fertilizers, manures and other chemicals to agricultural fields is a continuous practice that is required for the optimum crop production. The rate of fertilizer application to soils is often determined by farmers based on the results of periodic soil sampling and analysis that were conducted prior to the cropping season. However conventional methods of soil sampling and analysis for soil variability in chemical characteristics are too timeconsuming and expensive for multi-seasonal monitoring over large-scale areas. Hence, remote sensing has been used as an alternative method for determining and mapping the physical and chemical characteristics of the soil.

High resolution aerial imagery were used to map the organic carbon (Chen et al., 2000), clay content (Sullivan et al., 2005), organic matter and Bray-1 phosphorus concentration (Varvel et al., 1999), total soil phosphorus, copper and sulfur (Sridhar et al., 2009a,b) in bare soils. Dematte et al. (2003) reported that chemical variations in soil resulting from fertilizer applications can be detected, based on the intensity of reflectance. Several studies showed the use of spectral reflectance to determine the soil color (Post et al., 2000), texture and particle size distribution (Chang et al., 2001), soil moisture (Lobell \& Asner, 2002), iron oxides (Ji et al., 2002), carbonates (Ben-Dor \& Banin, 1990), clay (Ben-Dor \& Banin, 1995), organic carbon (Dalal \& Henry, 1986; Morra et al., 1991; Reeves et al., 2002) organic matter (Henderson et al, 1992) and soil phosphorus (Bogreckci \& Lee, 2005, 2007; Sridhar et al., 2009a ).

In this chapter, we are focuing on the use of LANDSAT TM data to map the changes in elemental concentrations of the soils that were applied with sewage sludge.

\subsection{Land application of sewage sludge}

Application of treated sewage sludges (biosolids) to agricultural land has become a prominent and acceptable method of waste disposal in recent years. Largely because of the 1991 ban on ocean dumping of sewage sludge and the higher costs of sludge incineration and land-filling, the application of sewage sludge to agricultural fields has gained momentum. Sewage sludge is the solid, semi-solid or liquid residue generated during the 
treatment of domestic sewage in waste water treatment plants (USEPA, 2002). Sewage sludge that is land applied has to meet the treatment criteria and the standard pollutant and pathogen limits set by USEPA under Part 503 rule (USEPA, 2002).

Biosolids are known to improve soil physical characteristics (Epstein et al., 1975; Wei et al., 1985), increase the organic matter and cation exchange capacity and supply the nutrients required for crop growth (Sommers, 1977; Singh \& Agrawal, 2008). However, the potential for excess application of biosolids, resulting in a build up of nitrogen, phosphorus (Mantovi et al., 2005), zinc, copper, lead (Mantovi et al., 2005; Udom etal., 2004; Nyamangara \& Mzezewa, 1999) and cadmium (Bergkvist et al., 2003) in the surface soils of agricultural fields continues to be an area of concern. Accumulation of phosphorus at high concentrations is a major environmental concern, as it affects the water quality of lakes and rivers in the event of runoff (Shober \& Sims, 2003).

Hence, there is an increasing need to continuously monitor the extent of soil contamination in biosolid-applied fields. Even though conventional methods of soil sampling and testing are being used for this purpose, they are often expensive, time-consuming and unsuitable for mapping soil contamination over large areas. The addition of soil contaminants as a result of biosolid application tend to be concentrated in surface soil samples (Mantovi et al., 2005; Bergkvist et al., 2003; Udom etal., 2004; Nyamangara \& Mzezewa, 1999).

\section{Methodology}

\subsection{Soil sampling and chemical analysis}

Two adjacent agricultural fields, F34 and F11, that received a cummulative amount of 34 ton acre $^{-1}\left(76 \mathrm{Mg} \mathrm{hac}^{-1}\right)$ and 11 ton acre ${ }^{-1}\left(25 \mathrm{Mg} \mathrm{hac}^{-1}\right)$ of Class B biosolids on a dry weight basis during the period of 1985-2002 were selected for this study (Fig 1). Soil samples were collected at 0,30 , and $50 \mathrm{~cm}$ depths from each of the 70 sampling locations across the two fields. These fields were selected because they are representative of large areas of northwest Ohio where land application of biosolids has become an important agricultural practice. The soil samples were collected on May 19 of 2005, one day prior to LANDSAT over pass, and the sampling locations were marked using a Trimble GeoExplorer (Trimble Navigation Limited, CA, USA) global positioning system (GPS) receiver. The collected soil samples were dried and passed through a $2 \mathrm{~mm}$ sieve. The moisture content of the surface soil samples was measured using the gravimetric method. The source of sewage sludge for the agricultural fields in the study area was the Oregon Waste Water Treatment Plant (OWWTP). The basic composition of the sewage sludge of OWWTP is typical of the biosolids produced in Ohio, which is regulated within the limits set by the U.S. Environmental Protection Agency (USEPA) under the part 503 rule (USEPA 2002).

Soil samples (approximately $0.5 \mathrm{~g}$ ) were digested with concentrated $\mathrm{HNO}_{3}$, according to USEPA method SW846-3051A (USEPA, 1998) using a Mars Xpress microwave digestion unit (CEM, Matthews, NC, USA). The digested solution was filtered and then analyzed for As, B, $\mathrm{Be}, \mathrm{Ca}, \mathrm{Cd}, \mathrm{Cr}, \mathrm{Cu}, \mathrm{Fe}, \mathrm{K}, \mathrm{Mg}, \mathrm{Mn}, \mathrm{Mo}, \mathrm{Na}, \mathrm{Ni}, \mathrm{P}, \mathrm{Pb}, \mathrm{S}$, Se, Si and $\mathrm{Zn}$ concentrations using inductively coupled plasma-optical emission spectrometry (ICP-OES) (IRIS Intrepid II, Thermo Scientific, Waltham, MA, USA). Quantification was achieved using matrix matched high and low concentration standards for each element. Internal quality controls and blanks were run every ten samples in order to quantify cross-contamination and recovery efficiencies. 
Analysis of variance (ANOVA) was used to compare the accumulation of each element in the F34 and F11 fields using SAS version 9.1 statistical software (SAS Institute Inc., Cary, NC, USA). An alpha level of 0.05 was used to determine the significance.

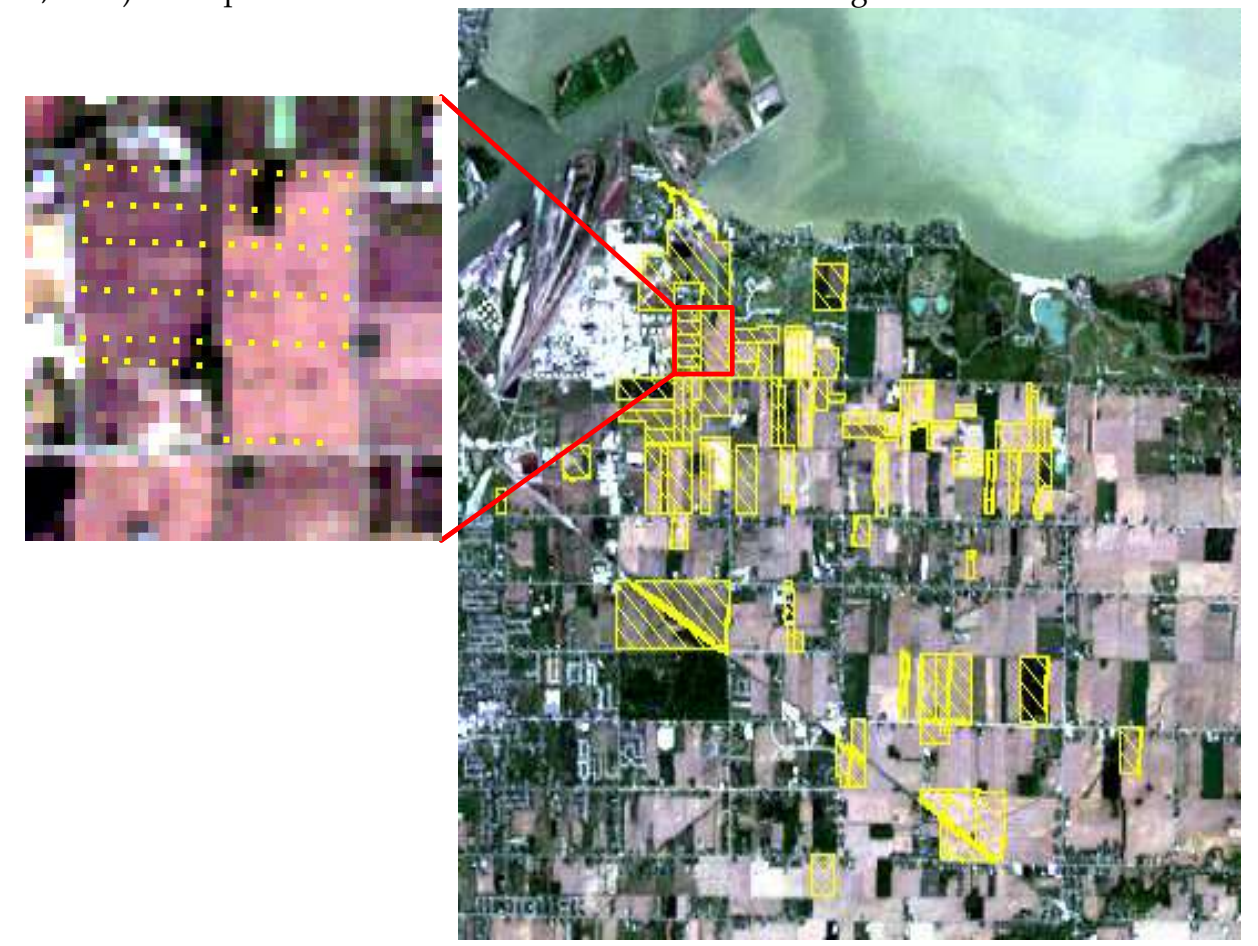

Fig. 1. The LANDSAT 5 TM natural color image (TM bands 1, 2, and 3 displayed as BGR, respectively) obtained on May 20, 2005 showing the eastern part of Lucas County in northwest Ohio; this area drains into Lake Erie, which is towards the northern side (top) of the image. The fields permitted for Class B biosolid application in the area are outlined in the image. The fields marked with red borders are the experimental fields used in this study. Soil sampling locations of the study area were shown as yellow dots in the insert image. (Reprinted from Science of Total Environment 47, Sridhar et al., 2009a, with permission from Elsevier)

\subsection{LANDSAT data acquisition and analysis}

The LANDSAT image frames of May 20 and June 5, 2005, covering the study area were downloaded soon after soil sampling. They were then processed with the ER Mapper image processing software, a commercial product of Earth Resources Mapping, Inc. The study area was located within the LANDSAT overpass region of Path 20, Row 31. The natural color image of the study area, overlaid with outlines of the fields permitted for Class B biosolid applications, is shown in Figure 1. The locations of all the 70 soil sampling points collected one day prior to LANDSAT 5 overpass were also shown separately in Figure 1 on the natural color image of the study area. The study site was dry, without any vegetation, implying that image spectral reflectances represent the spectral reflectance of soil. The 
procedure for developing the GIS database of the Class B biosolid permitted fields in Wood and Lucas counties of northwest Ohio was reported in detail by McNulty (2005).

Based on the locations of the 70 soil samples, the dark object subtracted (DOS) pixel values corresponding to the LANDSAT TM bands 1-5 and 7 were derived from the original May 20, 2005 image. The spectral range of these LANDSAT TM bands are as follows: Band 1: 450-520 nm; Band 2: 520-600 nm; Band 3: 630-690 nm; Band 4: 760-900 nm; Band 5: 1550$1750 \mathrm{~nm}$; and Band 7: 2080-2350 nm. The dark object of each spectral band is defined as one value less than the minimum digital number found in all the pixels of the image (Vincent et al., 2004). The detailed procedure for DOS and its effects on removal of atmospheric haze was given in Vincent (1997) and Vincent et al. (2004). From the DOS-corrected digital number (DN) values of the six LANDSAT single bands, 15 non-reciprocal spectral ratios were calculated. These spectral ratios are: $R_{2,1} ; R_{3,1} ; R_{3,2} ; R_{4,1} ; R_{4,2} ; R_{4,3} ; R_{5,1} ; R_{5,2} ; R_{5,3} ; R_{5,4} ; R_{7,1}$; $\mathrm{R}_{7,2} ; \mathrm{R}_{7,3} ; \mathrm{R}_{7,4} ; \mathrm{R}_{7,5}$ where $\mathrm{R}$ represents the ratio and the numbers represent the LANDSAT TM band numbers (Vincent, 1997). The spectral ratios were calculated using the MINITAB statistical software (MINITAB Inc., State College, PA, USA).

\subsection{LANDSAT TM best spectral ratio model development and validation}

The relationship between the chemical concentrations of the surface soil samples and the DOS DN values corresponding to the six single bands and the 15 non-reciprocal spectral ratios were developed by regression analysis. Using the MINITAB regression analysis component the best subsets regression was employed, and only the top two models with highest $\mathrm{R}^{2}$ adjusted values were chosen to report for each number of variables. The best subsets procedure was used for sequentially entering independent variables one at a time to improve the regression equation's predictive ability. The reported models from the best subset regression output were tested for autocorrelation with a Durbin-Watson (DW) statistical test (Durbin \& Watson, 1951). This tests for autocorrelation in the input parameters. Finally, the model which had the highest $\mathrm{R}^{2}$ adjusted and that also passed the DW test was selected as the best model for given inputs. This procedure was reported in detail elsewhere by Vincent (2000) and Vincent et al. (2004). The identified best model was then applied to the same May 20, 2005, LANDSAT image, which was used in developing the model to map the elemental concentration of the surface soils. The model was also applied and validated using the June 5, 2005, LANDSAT image, which was obtained 17 days after the soil sampling. In the LANDSAT images that were applied with the best model, masks were created to limit the display to only bare soil fields.

\section{Results and discussion}

\subsection{Soil chemical concentration}

The chemical concentration of the soils at 0,30 and $50 \mathrm{~cm}$ depths and the moisture content of the surface soils in both the F34 and F11 treated fields are shown in Table 1. Among all the chemicals that were analyzed, the accumulation of $\mathrm{Ba}, \mathrm{Cd}, \mathrm{Cu}, \mathrm{S}$ and $\mathrm{P}$ were significantly $(p<0.05)$ higher in the surface soils of F34, compared to F11 (Table 1). There was no significant difference in the chemical concentrations at 30 and $50 \mathrm{~cm}$ depths among the F34 and F11 soils. Also, the moisture content of the surface soils in both the fields was similar (Table 1). The soils were of the prevalent latty silty clay type with surface soils having 40$55 \%$ of clay and 3-5\% of organic matter (Soil Survey Staff, 2007). 


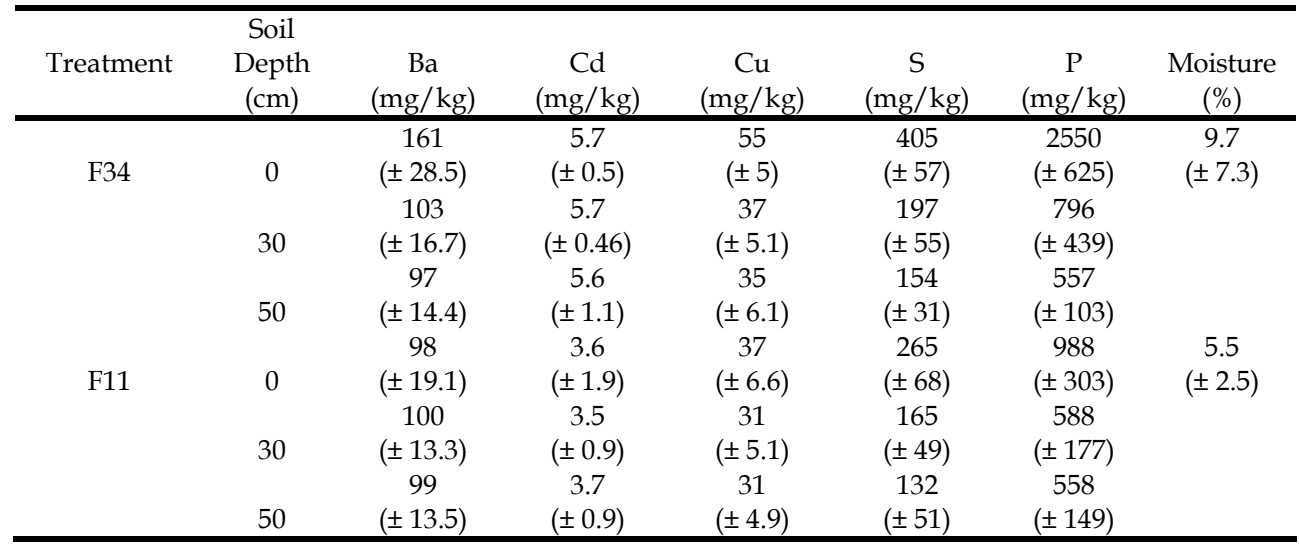

Table 1. Chemical concentration of soils applied with 34 ton acre-1 (F34) and 11 ton acre-1 (F11) of class B biosolids. The given values are means \pm standard deviation of 35 replicates. (Reprinted from Science of Total Environment 47, Sridhar et al., 2009a, with permission from Elsevier)

\subsection{LANDSAT spectral ratio model}

Regression equations were established to determine the chemical concentrations of $\mathrm{Ba}, \mathrm{Cd}$, $\mathrm{Cu}, \mathrm{S}$ and $\mathrm{P}$, which are significantly $(p<0.05)$ higher in the surface soils of F34 compared to F11, using the DOS-corrected six TM bands and the 15 non-reciprocal spectral ratios. The best spectral ratio input models that pass the DW test of significance along with their $\mathrm{R}^{2}$ adjusted and standard error values are given in Table 2.

\begin{tabular}{cccc}
\hline Chemical & Best spectral ratio model & $\mathrm{R}^{2}$ Adjusted $(\%)$ & SE (mg/kg) \\
\hline Phosphorus & $4156-1690(\mathrm{R} 51)+2257(\mathrm{R} 73)$ & 67.9 & 531.2 \\
Copper & $75-17.9(\mathrm{R} 51)+21.9(\mathrm{R} 73)$ & 59 & 6.9 \\
Sulfur & $507-14.7(\mathrm{R} 51)+214(\mathrm{R} 73)$ & 49.3 & 66.8 \\
\hline
\end{tabular}

Table 2. Best spectral ratio input models for phosphorous, copper, and sulfur that pass the Durbin Watson test along with the values of $\mathrm{R}^{2}$ adjusted and SE (standard error). Note: The models developed for $\mathrm{Cd}$ and $\mathrm{Ba}$ did not pass the Durbin Watson test at $5 \%$ level of significance. (Reprinted from Science of Total Environment 47, Sridhar et al., 2009a, with permission from Elsevier).

None of the single band models passed the DW test. Phosphorus had the highest $\mathrm{R}^{2}$ adjusted value $(67.9 \%)$ followed by $\mathrm{Cu}$ among the chemical attributes that passed the DW test (Table 2) and are considered for mapping with LANDSAT TM data. Hence, only the P and $\mathrm{Cu}$ results were shown in this paper. The $\mathrm{P}$ values obtained from chemical analysis of the 70 surface soil sampling locations versus the predicted values of $\mathrm{P}$ for the same locations 
obtained by applying the P spectral ratio model $\mathrm{P}(\mathrm{mg} / \mathrm{kg})=4156-1690$ (R51) +2257 (R73) to the May 20, 2005, LANDSAT TM frame is given in Figure 3.

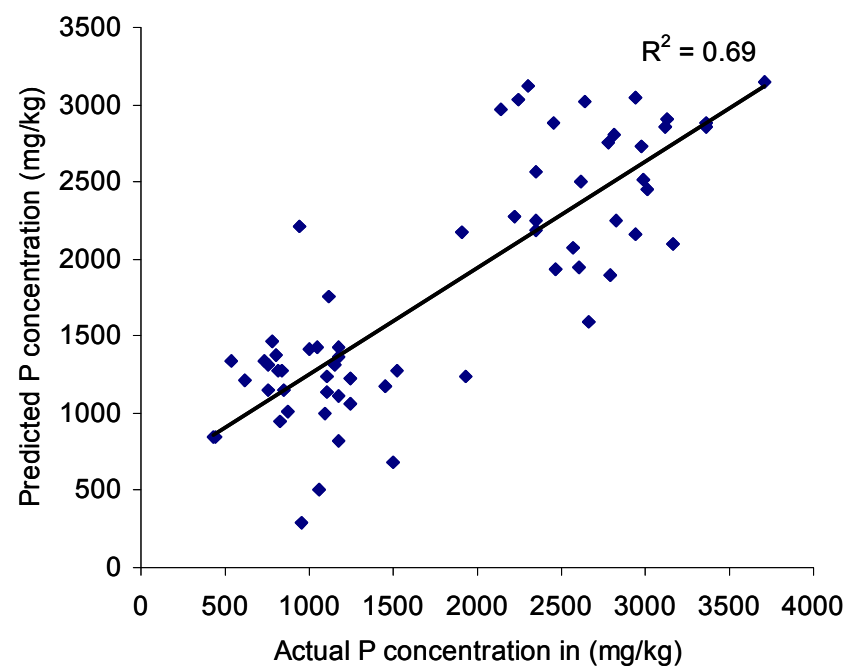

Fig. 3. Actual versus predicted $P$ concentration (in $\mathrm{mg} / \mathrm{kg}$ ) of surface soil samples using the dark object subtracted best P spectral ratio model being applied to the LANDSAT 5 TM frame of May 20, 2005, which was also used for developing the model. (Reprinted from Science of Total Environment 47, Sridhar et al., 2009a, with permission from Elsevier)

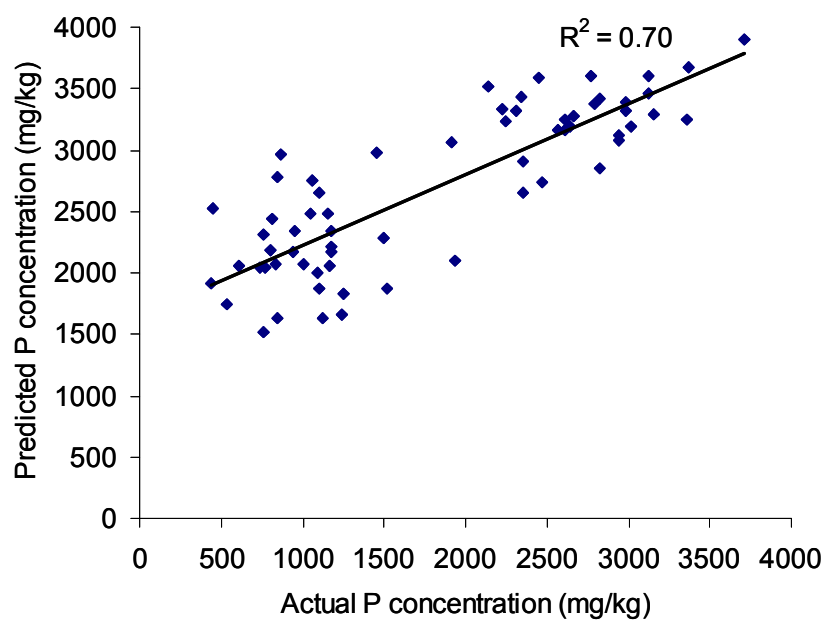

Fig. 4. Actual versus predicted $P$ concentration (in $\mathrm{mg} / \mathrm{kg}$ ) of surface soil samples using the dark object subtracted best $\mathrm{P}$ spectral ratio model being applied to the LANDSAT $5 \mathrm{TM}$ frame of June 5, 2005. (Reprinted from Science of Total Environment 47, Sridhar et al., 2009a, with permission from Elsevier). 
The P spectral ratio model was also applied to the June 5, 2005 LANDSAT image frame and the predicted $\mathrm{P}$ values were plotted against the $\mathrm{P}$ values obtained by the soil analysis (Fig. 4). The model performed well in predicting the $\mathrm{P}$ concentrations of surface soil when applied to either of the LANDSAT TM images.
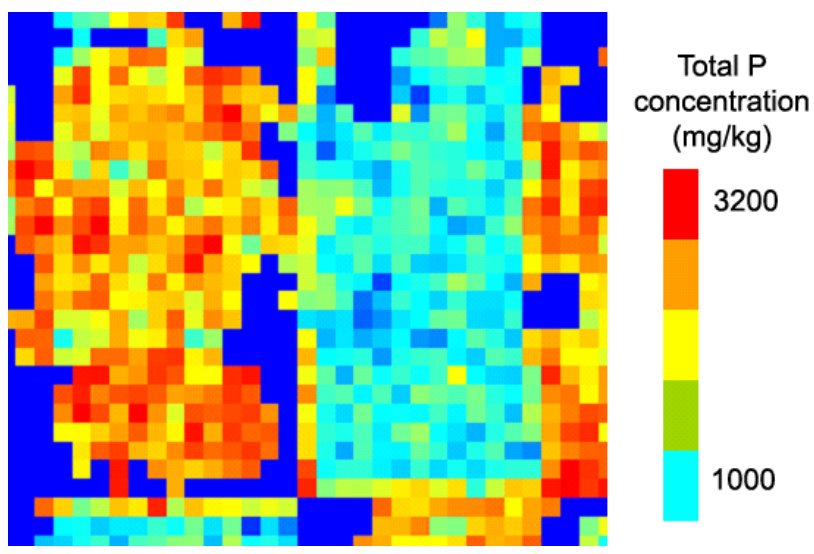

Fig. 5. Image showing the total P concentration $(\mathrm{mg} / \mathrm{kg})$ in surface soil samples of fields F34 (left side of the image) and F11 (right side of the image), displayed as red (high P content) to Turquoise (low $\mathrm{P}$ content), obtained by applying the best $\mathrm{P}$ spectral ratio model to the LANDSAT 5 TM frame of May 20, 2005 which was also used for developing the model. (Reprinted from Science of Total Environment 47, Sridhar et al., 2009a, with permission from Elsevier)
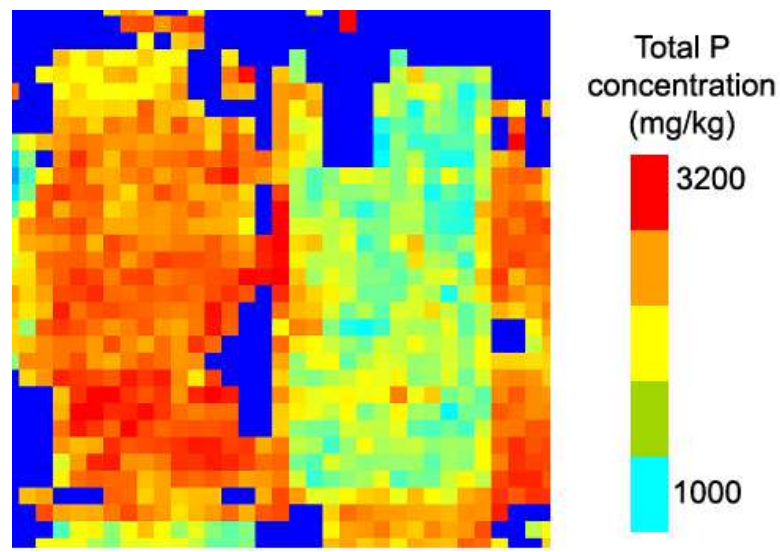

Fig. 6. Image showing the total P concentration $(\mathrm{mg} / \mathrm{kg})$ in surface soil samples of fields F34 (left side of the image) and F11 (right side of the image), displayed as red (high P content) to Turquoise (low $\mathrm{P}$ content), obtained by applying the $\mathrm{P}$ spectral ratio model to the LANDSAT 5 TM frame of June 5, 2005. (Reprinted from Science of Total Environment 47, Sridhar et al., 2009a, with permission from Elsevier) 
The application of the best P spectral ratio model to the LANDSAT 5 TM frame of May 20, 2005, which was also used in developing the model, is shown in figure 5 . The redder color in this image corresponds to higher amounts of $P$ in surface soil. Figure 6 shows the image of the same spectral ratio model that was developed using the LANDSAT 5 frame of May 20, 2005, being applied to the LANDSAT 5 frame of June 5, 2005. Note that the P concentration in the F34 field is significantly higher than the F11 field in both the images (Fig 5 and 6). The application of the best P spectral ratio model to the May 20, 2005, LANDSAT TM image, showing the part of the watershed that drains into Lake Erie, is given in Figure 7. The fields outlined in this figure are permitted for Class B biosolid application.

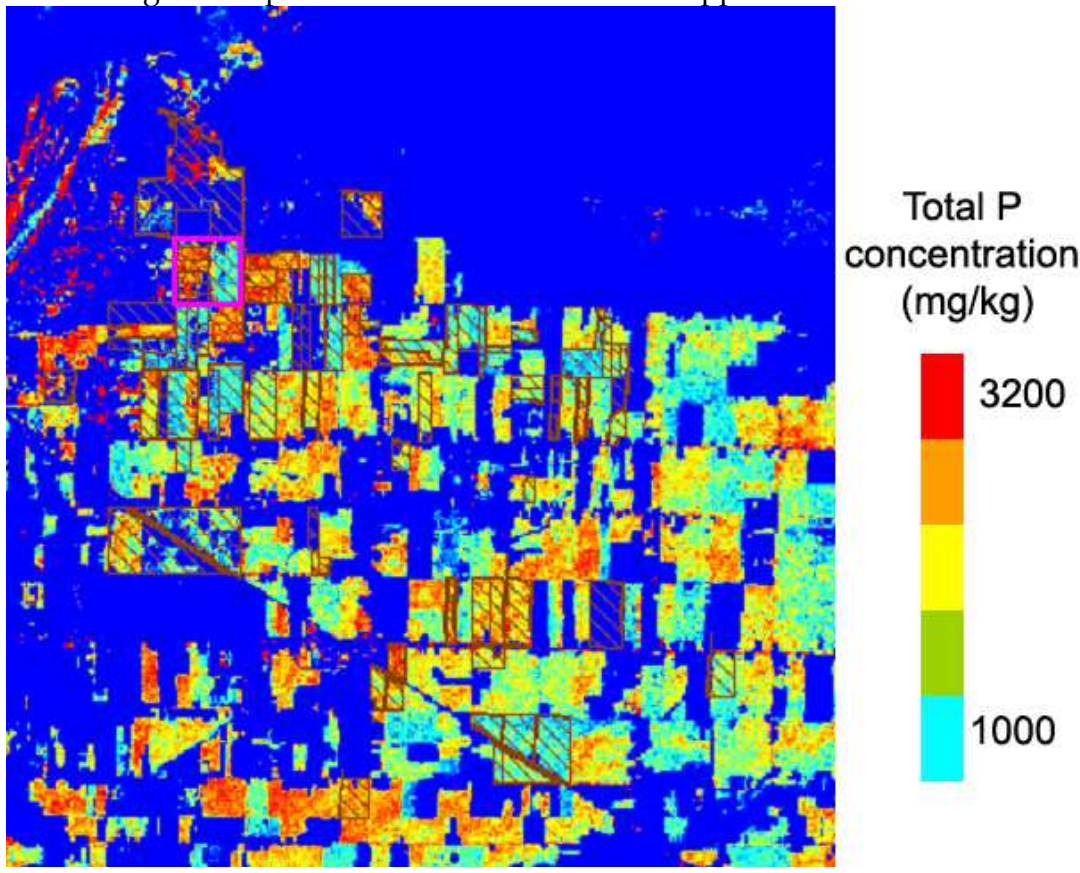

Fig. 7. The total P concentration $(\mathrm{mg} / \mathrm{kg}$ ) in surface soil samples of the bare soil fields in the eastern part of the Lucas County of northwest Ohio, which is a part of the drainage basin of Lake Erie, which is located at the northern side (top) of the image. The image is obtained by applying the P spectral ratio model to the LANDSAT 5 TM frame of May 20, 2005 which was used for developing the model. The fields permitted for Class B biosolid application in the vicinity are outlined in the image. The fields marked with a pink border are the experimental fields used in this study. Not all of the permitted fields in this image would have recently received sewage sludge, and some non-permitted fields could have recently received other types of fertilizers. (Reprinted from Science of Total Environment 47, Sridhar et al., 2009a, with permission from Elsevier)

The $\mathrm{Cu}$ values obtained from chemical analysis of the 70 surface soil sampling locations versus the predicted values of $\mathrm{Cu}$ for the same locations obtained by applying the $\mathrm{Cu}$ spectral ratio model $\mathrm{Cu}(\mathrm{mg} / \mathrm{kg})=75-17.9(\mathrm{R} 51)+21.9(\mathrm{R} 73)$ to the May 20, 2005, LANDSAT TM frame is given in Figure 8. The $\mathrm{Cu}$ spectral ratio model was also applied to the June 5, 
2005 LANDSAT image frame and the predicted $\mathrm{Cu}$ values were plotted against the $\mathrm{Cu}$ values obtained by the soil analysis (Fig. 9). The model performed well in predicting the $\mathrm{Cu}$ concentrations of surface soil when applied to either of the LANDSAT TM images.

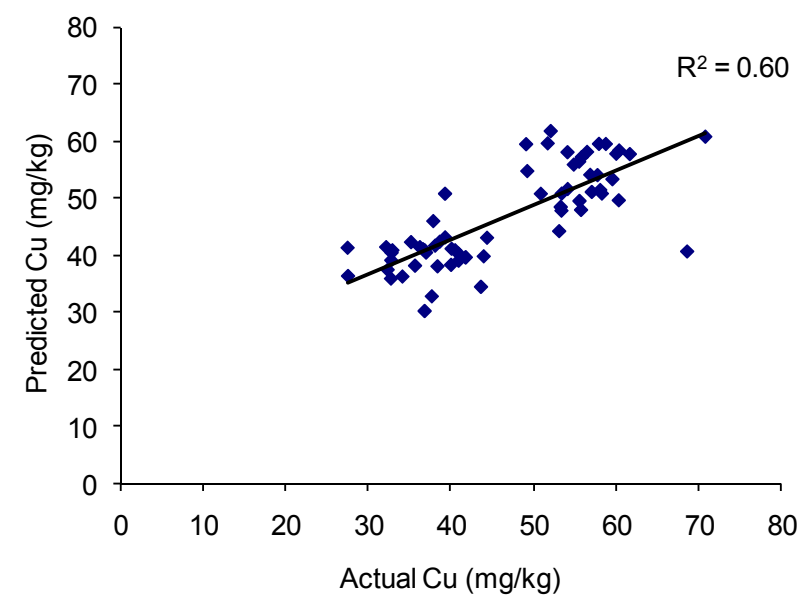

Fig. 8. Actual versus predicted $\mathrm{Cu}$ concentration (in $\mathrm{mg} / \mathrm{kg}$ ) of surface soil samples using the dark object subtracted best $\mathrm{Cu}$ spectral ratio model being applied to the LANDSAT $5 \mathrm{TM}$ frame of May 20, 2005, which was also used for developing the model.

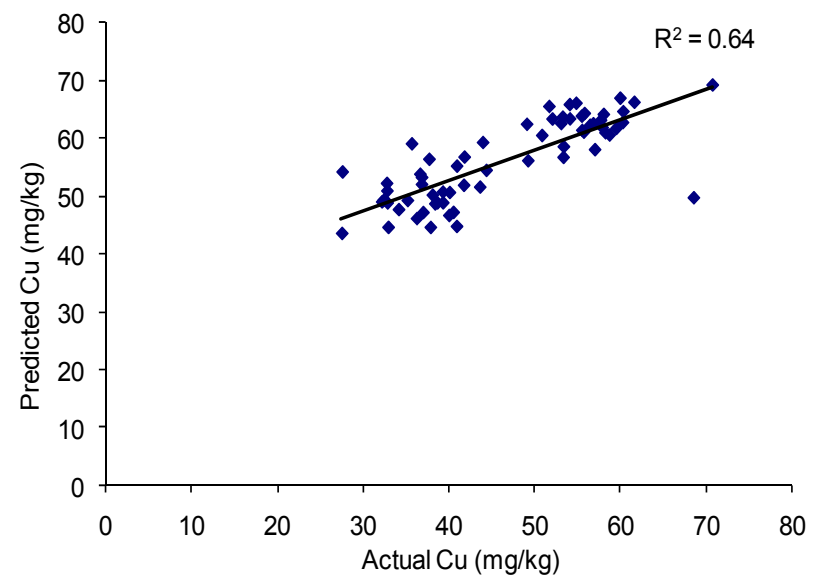

Fig. 9. Actual versus predicted $\mathrm{Cu}$ concentration (in $\mathrm{mg} / \mathrm{kg}$ ) of surface soil samples using the dark object subtracted best $\mathrm{Cu}$ spectral ratio model being applied to the LANDSAT 5 TM frame of June 5, 2005. 


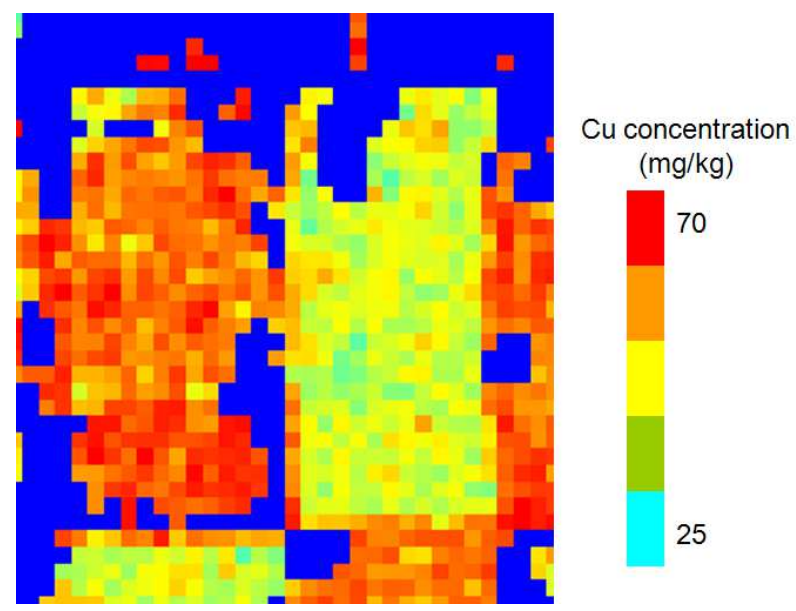

Fig. 10. Image showing the total $\mathrm{Cu}$ concentration $(\mathrm{mg} / \mathrm{kg})$ in surface soil samples of fields F34 (left side of the image) and F11 (right side of the image), displayed as red (high $\mathrm{Cu}$ content) to Turquoise (low $\mathrm{Cu}$ content), obtained by applying the best $\mathrm{Cu}$ spectral ratio model to the LANDSAT 5 TM frame of May 20, 2005 which was also used for developing the model.

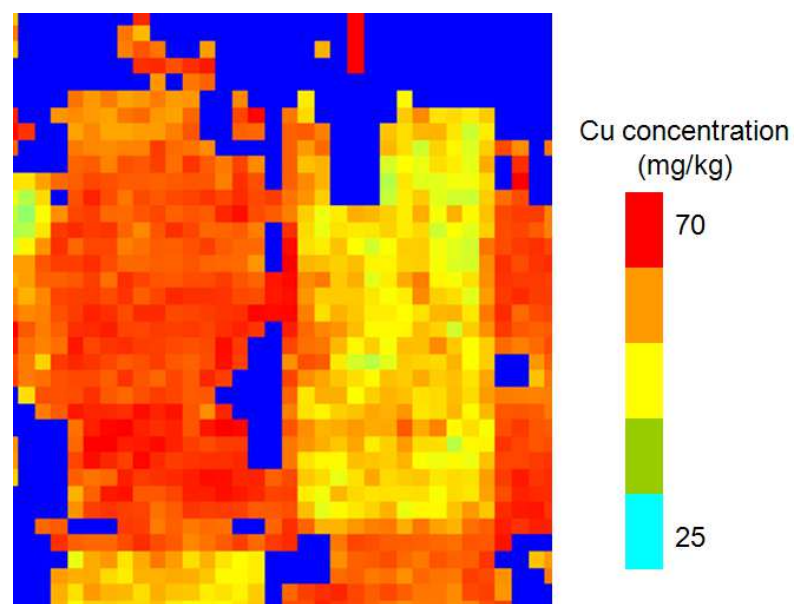

Fig. 11. Image showing the total $\mathrm{Cu}$ concentration $(\mathrm{mg} / \mathrm{kg})$ in surface soil samples of fields F34 (left side of the image) and F11 (right side of the image), displayed as red (high $\mathrm{Cu}$ content) to Turquoise (low $\mathrm{Cu}$ content), obtained by applying the $\mathrm{P}$ spectral ratio model to the LANDSAT 5 TM frame of June 5, 2005.

The application of the best $\mathrm{Cu}$ spectral ratio model to the LANDSAT 5 TM frame of May 20, 2005, which was also used in developing the model, is shown in figure 10. The redder color in this image corresponds to higher amounts of $\mathrm{Cu}$ in surface soil. Figure 11 shows the image of the same spectral ratio model that was developed using the LANDSAT 5 frame of May 20, 2005, being applied to the LANDSAT 5 frame of June 5, 2005. Note that the $\mathrm{Cu}$ 
concentration in the F34 field is significantly higher than the F11 field in both the images (Fig 10 and 11). The application of the best $\mathrm{Cu}$ spectral ratio model to the May 20, 2005, LANDSAT TM image, showing the part of the watershed that drains into Lake Erie, is given in Figure 12.

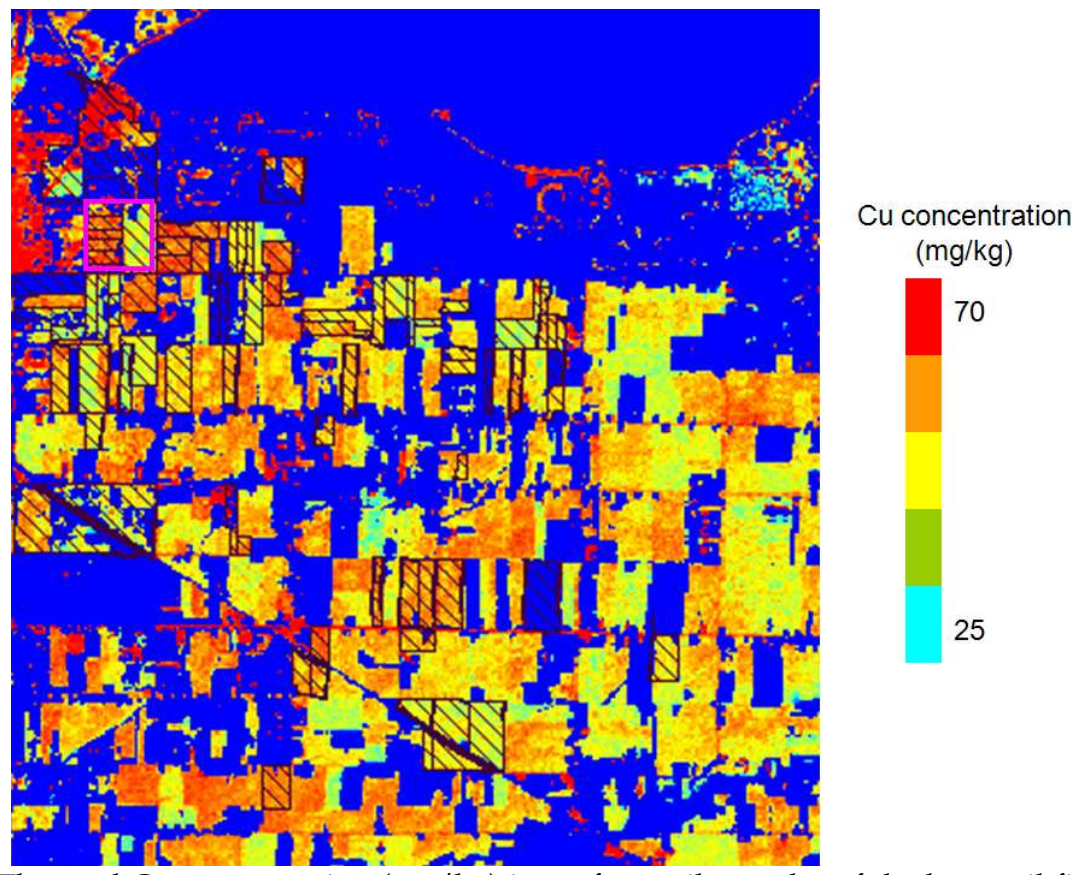

Fig. 12. The total $\mathrm{Cu}$ concentration $(\mathrm{mg} / \mathrm{kg})$ in surface soil samples of the bare soil fields in the eastern part of the Lucas County of northwest Ohio, which is a part of the drainage basin of Lake Erie, which is located at the northern side (top) of the image. The image is obtained by applying the $\mathrm{Cu}$ spectral ratio model to the LANDSAT 5 TM frame of May 20, 2005 which was used for developing the model. The fields permitted for Class B biosolid application in the vicinity are outlined in the image. The fields marked with a pink border are the experimental fields used in this study.

The analytical results showed that the accumulation of $\mathrm{P}$ and $\mathrm{Cu}$ in surface soil samples of F34 was about 2.6 and 1.5 times higher than for the F11 soils. This confirms the report of Chang et al. (1983) that five continuous years of biosolids application in two California soils at $0,22.5,45$ and 90 ton per hectare increased the total $P$ concentration of surface soil (0-15 $\mathrm{cm}$ ) from $515-540 \mathrm{mg} / \mathrm{kg}$ to $1092-1312,1657-2163$ and $2617-3470 \mathrm{mg} / \mathrm{kg}$, respectively. Similarly Maguire et al. (2000) reported that the concentration of total soil P in surface soils $(0-20 \mathrm{~cm})$ of biosolid amended soils was $738 \mathrm{mg} / \mathrm{kg}$, or nearly double the values in unamended soils, where the total soil $\mathrm{P}$ was $403 \mathrm{mg} / \mathrm{kg}$. High concentrations of $\mathrm{Cd}$ and $\mathrm{Cu}$ in the surface soils of F34 compared to F11 agree with the reports of Nyamangara and Mzezewa (1999), that the long-term application of biosolid increases the accumulation of $\mathrm{Cd}$ and $\mathrm{Cu}$ in the surface soils 


\section{Discussion}

LANDSAT TM data can be used to estimate and map some chemical characteristics of soils, such as total phosphate content, as shown in this study. Our results enabled us to conclude that remotely sensed imagery of bare soil fields can be used to quantify and map the spatial variation of total $\mathrm{P}$ and $\mathrm{Cu}$ concentration in surface soils. The technology is simple enough to be applied to the entire watershed. The $\mathrm{P}$ and $\mathrm{Cu}$ spectral ratio models were more robust and reliable than the single band input models and can be applied to bare soil fields with low $(<13 \%)$ soil moisture.

Nanni and Dematte (2006) have successfully employed LANDSAT TM data to estimate the sand, silt, clay, organic matter, cation exchange capacity (CEC) and sum of cations in Brazilian soils. They derived spectral reflectance values from the corrected LANDSAT image to develop multiple regression equations in order to estimate the different physical and chemical characteristics of the soils; however, no soil maps were presented in that study (Nanni \& Dematte, 2006). Our study is significant because it represents the first successful effort in using LANDSAT TM data to estimate and map P concentration in surface soils. We also successfully validated the $\mathrm{P}$ spectral ratio model by applying to another LANDSAT image obtained on June 5, 2005.

Aerial imagery was used to map the organic carbon (Chen et al., 2000), clay content (Sullivan et al., 2005), organic matter and Bray-1 phosphorus concentration (Varvel et al., 1999) and LANDSAT TM imagery was used to estimate the physical and chemical properties (Nanni \& Dematte, 2006) of surface soils in the previous studies. However, the algorithms developed in these studies were based on the reflected image intensity values of the soils, which required correction for atmospheric haze with atmospheric models before applying the algorithms to another date. The P spectral ratio model developed in our study is based on the DOS-corrrected spectral ratios and is more robust that any model that could be derived from a combination of single spectral bands. Vincent et al. (2004) showed that the DOS spectral ratio models were more robust than single band models and can be applied with reasonable accuracy to different times of data collection, though their subject was cyanobacteria blooms in lakes or streams, and the present study is about P concentrations in bare soils on dry land.

By applying our $\mathrm{P}$ and $\mathrm{Cu}$ spectral ratio model, we can identify and map the $\mathrm{P}$ and $\mathrm{Cu}$ concentration in surface soils as a result of biosolid application. Because $\mathrm{P}$ accumulation in soils can also result from the application of biosolids, animal manures, and man-made fertilizers, this research has significant implications in identifying the fields with high concentrations of surface soil P, thus helping implementation of P-based management practices on agricultural fields, with an aim toward reduction of P runoff into nearby surface water bodies.

Shober and Sims (2003) reported that twenty-four of the states and territories in the United States now have regulations to restrict the land application of biosolids, based on phosphorus concentration in soil. Thirteen of these 24 states have established actual numerical limits for soil test phosphorus (STP), with an aim to cease the application of biosolids once these limits are reached. As the total soil P and STP are linearly related to each other (Allen \& Mallarino, 2006), our P spectral ratio model can be used to monitor P levels in surface soils.

The remainder of this chapter is devoted for the presentation of a sample application which demonstrates how quantitative remote sensing of soil $\mathrm{P}$ and $\mathrm{Cu}$ concentrations can be used 
to meet the variety of information needs. This particular case study shows the use of our remote sensing models for monitoring a recent environmental disaster.

\subsection{Sample application} a. Coal fly ash spill

A vast amount of fly ash, a by-product of coal incineration, was spilled over a wide area on December 22, 2008, at approximately 0100 hours EST, when an earthen wall of a fly ash disposal pond broke at the Tennessee Valley Authority (TVA) Kingston Fossil Plant, located at Harriman, Roane County, Tennessee (TVA, 2009; Fig 13). This is the largest environmental disaster of its kind involving a coal fly ash spill in the US history (New York Times, 2008). Approximately 5.4 million cubic yards of fly ash were spilled over an area of 300 acres outside the ash storage ponds. Fly ash was also spilled into the Emory River and the tributaries that flow into the Emory River, which serves as a source of drinking water (TVA, 2009; New York Times, 2008; Fig 13).

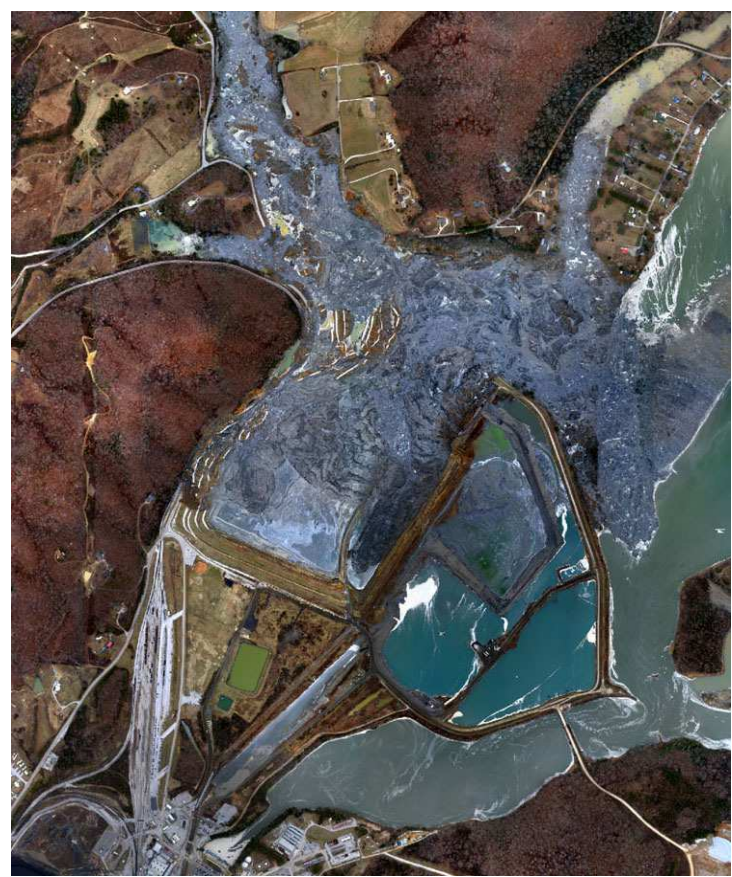

Fig 13. The aerial image of the Tennessee fly ash spill area acquired soon after the spill. (Image courtesy of Tennessee Valley Authority and can be viewed at http:/ / www.tva.gov/kingston/photo_gallery/pages/123002.htm) 
Accumulation of large amounts of fly ash as a result of coal combustion is becoming a major environmental concern in the United States. With the Nation's increasing demand for energy, the increase in coal combustion has required the disposal of large quantities of coal combustion residues. Approximately 131 million tons of coal combustion residues were generated within the United States in 2007, of which 36\% was disposed in landfills, $21 \%$ in surface impoundments, and the remainder was reused for beneficial purposes. There are approximately 300 landfills and 300 surface impoundment facilities used by 440 coal fired plants across the United States (Fig 13).

The physical and chemical properties of the fly ash generated at a given coal-fired plant depends on the nature of the coal being burned, type of the combustion method, and the storage and handling methods involved. In general, fly ash is substantially rich in many elements (including heavy metals) and is usually stored in either landfills or artificial lagoons on open land. The general chemical composition of fly ash is given in Table 3 (Page et al., 1979).

\begin{tabular}{cc}
\hline Element & Fly ash concentration \\
\hline Major elements (\%) & $0.1-17.3$ \\
$\mathrm{Al}$ & $0.11-22.2$ \\
$\mathrm{Ca}$ & $1-29$ \\
$\mathrm{Fe}$ & $0.04-7.6$ \\
$\mathrm{Mg}$ & $0.01-2.03$ \\
$\mathrm{Na}$ & $0.15-3.5$ \\
$\mathrm{~K}$ & $0.002-0.004$ \\
$\mathrm{~S}$ & $0.04-0.8$ \\
$\mathrm{P}$ & \\
Trace elements (ppm) & $2.3-6300$ \\
$\mathrm{As}$ & $10-618$ \\
$\mathrm{~B}$ & $0.7-130$ \\
$\mathrm{Cd}$ & $7-520$ \\
$\mathrm{Co}$ & $10-1000$ \\
$\mathrm{Cr}$ & $14-2800$ \\
$\mathrm{Cu}$ & $0.02-1$ \\
$\mathrm{Hg}$ & $58-3000$ \\
$\mathrm{Mn}$ & $7-160$ \\
$\mathrm{Mo}$ & $6.3-4300$ \\
$\mathrm{Ni}$ & $3.1-5000$ \\
$\mathrm{~Pb}$ & $0.2-134$ \\
$\mathrm{Se}$ & $10-3500$ \\
$\mathrm{Zn}$ & $-\mathrm{Page}$
\end{tabular}

Table 3. General chemical characteristics of Fly ash. (After Page et al., 1979; Reprinted from Photogrammetric Engineering and Remote Sensing 75, Sridhar et al., 2009b)

Mapping the spatial distribution of chemical concentrations as a result of fly ash spill is important for determining its effect on human and environmental health and for conducting remediation and recovery efforts. Previous studies have shown that fly ash pollution can be monitored through several methods: conventional soil sampling and analysis, measurement 
of Sr-87 to Sr-86 ratios in plant samples growing in the vicinity, and measurement of ferromagnetic mineral concentrations present within the fly ash by magnetic mapping. However, all of these methods are based on point measurements at the ground-level, requiring intensive sampling of large-scale contaminated areas, which is expensive, timeconsuming and sometimes not even possible as the areas may be sufficiently hazardous (e.g., poor slope stability) and inaccessible to scientists and engineers.

\section{b. LANDSAT TM Images}

Remote sensing has been used as an alternative method for determining and mapping the physical and chemical characteristics of exposed soils. In this study, we have used LANDSAT Thematic Mapper (TM) sensor data to identify and map the TVA's fly ash spill in Tennessee. The Thematic Mapper and Enhanced Thematic Mapper plus (ETM+) sensors were aboard the LANDSAT 5 and 7 respectively, each of which has a 16-day repeat cycle with a pixel size of $30 \mathrm{~m} \times 30 \mathrm{~m}$ for bands 1-5 and 7. Because the two satellites have an 8-day offset from one another, it is possible to obtain coverage of a given ground area every 8 days, though the TM sensor aboard LANDSAT 7 (called ETM+) has approximately a quarter of its pixels missing, due to the loss of its scan line converter since May 31, 2003. In order to monitor the before and after fly ash spill events of the Kingston fly ash plant, we downloaded LANDSAT 5 TM data acquired on November 20, 2008 (32 days before fly ash spill); December 22, 2008 (about 9 hours after fly ash spill) and February 1, 2009 (40 days after fly ash spill) for this study. The LANDSAT TM images were then processed with the ER Mapper image processing software, a commercial product of Earth Resources Mapping, Inc., as mentioned earlier for the sewage sludge study.

For the purpose of measuring the $\mathrm{P}$ and $\mathrm{Cu}$ concentrations in the exposed fly ash and soil in the spill vicinity, the spectral ratio models given in Table 2 were applied to each of the three LANDSAT TM images covering the fly ash spill study area.

\section{c. Results of Image Analysis}

Figure 14 shows the natural color images, total $\mathrm{P}$ and $\mathrm{Cu}$ concentration images of the fly ashspill vicinity for each of the following dates of LANDSAT TM overpass: November 20, 2008, December 22, 2008, and February 1, 2009, representing the periods of 32 days before the fly ash spill, 9 hours after, and 40 days after the fly ash spill, respectively. The fly ash is seen as a grey-colored area in the December 22, 2008 natural color imagery. Image interpretation of a standard natural color image (TM bands 1, 2, and 3 displayed as blue, green, and red, respectively) yields limited success for mapping the fly ash deposits because the contrast between fly ash and background soils is small in visible wavelength regions. The LANDSAT TM derived $\mathrm{P}$ concentrations range from 1,500 to $4,500 \mathrm{ppm}$ and the $\mathrm{Cu}$ concentrations from 25 to 75 ppm in the November, 2008 and February, 2009 images. We have assigned turquoise, yellow, orange and red colors to increasing $\mathrm{P}$ and $\mathrm{Cu}$ concentrations as indicated by the respective color coding bars in Figure 1. The intense red color in the December 22, 2008 image clearly stands out due to larger areas of high $\mathrm{P}$ and $\mathrm{Cu}$ concentrations exposures at the surface, compared to the November 20, 2008 image acquired before the fly ash spill. The 25 to $75 \mathrm{ppm}$ range of $\mathrm{Cu}$ concentrations derived from the December 22, 2008 image correlates well with the 29.9 to $69.4 \mathrm{ppm}$ range of $\mathrm{Cu}$ values obtained through laboratory analysis from eight (8) ash sampling locations collected from 
December 23, 2008 through January 5, 2009 in the fly ash spill vicinity (Tetra Tech, 2009). The P concentrations were not reported through soil analysis (Tetra Tech, 2009).

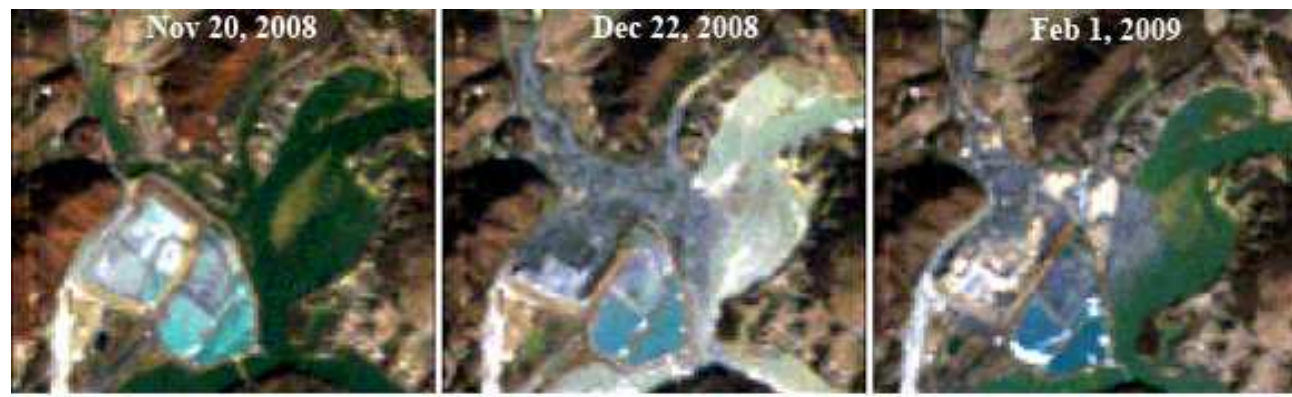

Natural color images showing LANDSAT bands 1,2 and 3 as blue, green and red repsectively
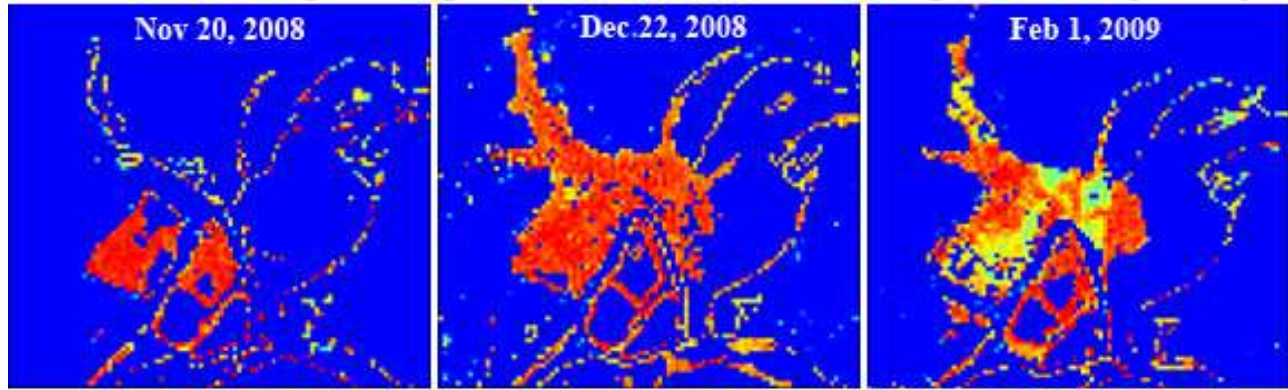

Phosphorus concentration in ppm:

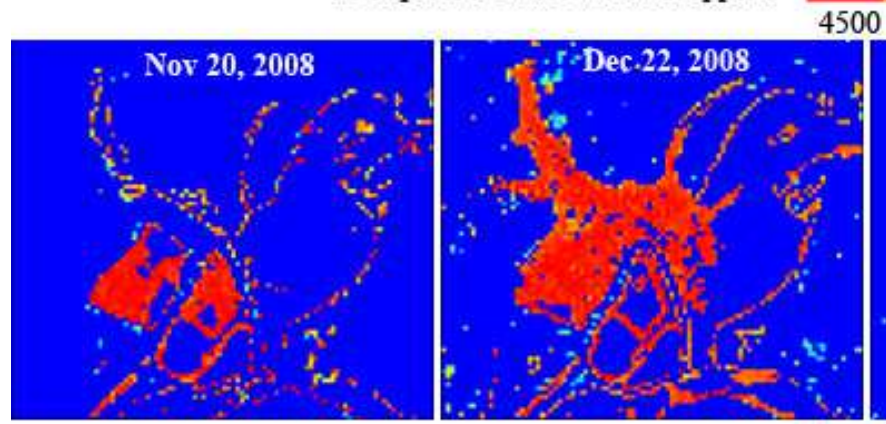

4500

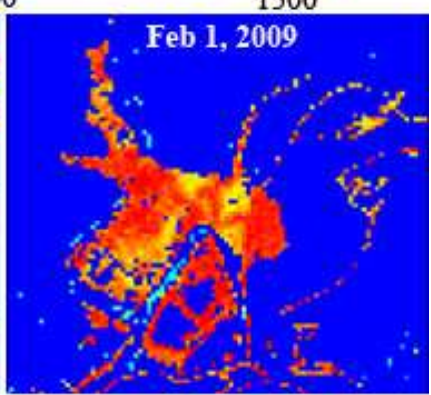

Copper concentration in ppm:

75

25

Fig. 14. The LANDSAT TM images of the Tennessee fly ash spill area acquired on November 20, 2008 (32 days before fly ash spill); December 22, 2008 (9 hours after fly ash spill) and February 1, 2009 (40 days after fly ash spill), respectively. The images in the rows 1-3 represent the natural color image, surface $\mathrm{P}$ concentration image, and surface $\mathrm{Cu}$ concentration image, respectively. (Reprinted from Photogrammetric Engineering and Remote Sensing 75, Sridhar et al., 2009b, with permission from the American Society for Photogrammetry \& Remote Sensing) 
In November, before the fly ash spill, the high concentrations of $\mathrm{P}$ and $\mathrm{Cu}$ were shown to be confined to the fly ash ponds. In December, a large extent of increased $\mathrm{P}$ and $\mathrm{Cu}$ concentrations is clearly evident towards the northern and north eastern side of the ash holding ponds as shown in Figure 14. These high $\mathrm{P}$ and $\mathrm{Cu}$ concentration features agree with the fly ash spill towards the northern and north eastern sides of the ash holding ponds (TVA, 2009). In February, the $\mathrm{P}$ and $\mathrm{Cu}$ concentrations mapped with the same LANDSAT TM algorithms were lower than those recorded in December. As an action item for dust suppression, TVA spread 85 tons of winter rye grass, 650 tons of straw, and other erosioncontrol mulch on the surface of the fly ash spill areas from January 3 through January 15, 2009 (TVA, 2009). For areas of where grass and straw were spread over, the February 1, 2009 image shows lower $\mathrm{P}$ and $\mathrm{Cu}$ concentrations, compared to the December 22, 2008 image. This series of images shows that LANDSAT TM data can be used to quantitatively monitor the remediation and recovery efforts of $\mathrm{P}$ and $\mathrm{Cu}$ contaminated sites.

\section{Conclusions}

In summary, the application of $\mathrm{P}$ and $\mathrm{Cu}$ mapping algorithms from LANDSAT TM images have allowed us to map and estimate the increase in surface concentrations of these two elements in surface soil samples. These results show the effective use of multispectral satellite image analysis in determining surface soil chemical concentrations. Compared to point measurements made by ground-based soil sampling and chemical analysis, the satellite-based measurements have a great advantage in mapping the spatial distribution and concentration of elements and chemical compositions over time. As LANDSAT TM has $30-\mathrm{m}$ spatial resolution, there is a measurement by the satellite for every $1 / 5$ th of an acre (the area covered by one pixel) during each overpass, which would be cost prohibitive for point measurements that require manual soil sample collection and laboratory analysis of each sample. Satellite monitoring of surface soil elemental concentrations for environmental purposes can surpass point measurements on the ground and measured in the laboratory, at least for $\mathrm{P}$ and $\mathrm{Cu}$. We have looked at several other elements for similar algorithms but found none as good as these two. The limitations of our spectral ratio models is that they were developed using bare soil fields that had a low soil moisture $(<13 \%)$ and the soils tested were of the prevalent soil type (Latty Silty Clay) in this region. Also the $\mathrm{P}$ and $\mathrm{Cu}$ concentration that went into these models were in the ranges of $700-3000$ 's and $30-60$ 's respectively. Thus we have no evidence that these models will be accurate for soils with $\mathrm{P}$ and $\mathrm{Cu}$ concentrations outside these limits and with different soil types of higher soil moisture contents. Further research is being done to test the model to determine the P and $\mathrm{Cu}$ concentration in surface soils of other soil types in this region.

\section{References}

Allen, B.L. \& Mallarino, A.P. (2006) Relationships between extractable soil phosphorus and phosphorus saturation after long-term fertilizer or manure application. Soil Sci Soc Am J, Vol.70, pp.454-463.

Ben-Dor, E. \& Banin, A. (1990) Near infrared reflectance analysis of carbonate concentration in soils. Appl. Spectrosc, Vol.44, pp.1064-1069. 
Ben-Dor, E. \& Banin, A. (1995) Near infrared analysis (NIRA) as a method to simultaneously evaluate spectral featureless constituents in soils. Soil Sci, Vol.4, pp.259-270.

Bergkvist, P.; Jarvis, N.; Berggren, D. \& Carlgren, K. (2003) Long-term effects of sewage sludge applications on soil properties, cadmium availability and distribution in arable soil. Agric. Ecosyst. Environ, Vol.97, pp.167-179.

Bogrekci, I. \& Lee, W.S. (2005) Spectral soil signatures and sensing phosphorus. Biosyst. Eng, Vol.92, pp.527-533.

Bogrekci, I. \& Lee, W.S. (2007) Comparison of ultraviolet, visible and near infrared sensing for soil phosphorus. Biosyst. Eng, Vol.96, pp.293-299.

Chang, A.C.; Page, A.L.; Sutherland, F.H. \& Grgurevic, E. (1983) Fractionation of phosphorus in sludge affected soils. J. Environ. Qual, Vol.12, pp.286-290.

Chang, C.W.; Laird, D.A.; Mausbach, M.J. \& Hurburgh, Jr C.R. (2001) Near-infrared reflectance spectroscopy - principal component regression analysis of soil properties. Soil Sci. Soc. Am. J, Vol.65, pp.480-490.

Chen, F.; Kissel, D.E.; West, L.T. \& Adkins, W. (2000) Field-scale mapping of surface soil organic carbon using remotely sensed imagery. Soil Sci. Soc. Am. J, Vol.64, pp.746753.

Dalal, R.C. \& Henry, R.J. (1986) Simultaneous determination of moisture, organic carbon, and total nitrogen by near infrared reflectance spectrophotometry. Soil Sci. Soc. Am. J, Vol.50, pp.120-123.

Dematte, J.A.M.; Pereira, H.S.; Nanni, M.R.; Cooper, M. \& Fiora, P.R. (2003) Soil chemical alterations promoted by fertilizer application assessed by spectral reflectance. Soil Sci, Vol.168, pp.730-747.

Durbin, J. \& Watson, G.S. (1951) Testing for serial correlation in least squares regression: II. Biometrica, Vol.38, pp.159-178.

Epstein, E.; Taylor, J.M. \& Chaney, R.L. (1975) Effects of sewage sludge on some soil physical properties. J. Environ. Qual, Vol.4, pp.139-142.

Henderson, T.L.; Baumgardner, M.F.; Franzmeieir, D.P.; Stott, D.E \& Coster, D.C. (1992) High dimensional reflectance analysis of soil organic matter. Soil Sci. Soc. Am. J, Vol.56, pp.865-872.

Ji, J.F.; Balsam, W.L.; Chen, J. \& Liu, L.W. (2002) Rapid and quantitative measurement of hematite and goethite in the Chinese Loess-Paleosol sequence by diffuse reflectance spectroscopy. Clay Miner, Vol.50, pp.208-216.

Lobell, D.B. \& Asner, G.P. (2002) Moisture effects on soil reflectance. Soil Sci. Soc. Am. J, Vol.66, pp.722-727.

Maguire, R.O.; Sims, J.T. \& Coale, F.J. (2000) Phosphorus fractionation in biosolids-amended soils: Relationship to soluble and desorbable phosphorus. Soil Sci. Soc. Am. J, Vol.64, pp.2018-2024.

Mantovi P, Baldoni G, Toderi G. Reuse of liquid, dewatered, and composted sewage sludge on agricultural land: effects of long-term application on soil and crop. Water Res. 2005; Vol.39, pp.289-296.

McNulty, W.S. (2005) The creation of a GIS database and the determination of sludge's spectral signature in an agricultural setting. M.S. Thesis. Department of Geology, Bowling Green State University, Bowling Green, OH, USA.

MINITAB Statistical Software Version 15. State College, PA: MINITAB Inc.; 2007-2008. 
Morra, M.J.; Hall, M.H. \& Freeborn, L.L. (1991) Carbon and nitrogen analysis of soil fractions using near infrared reflectance spectroscopy. Soil Sci. Soc. Am. J, Vol.55, pp.288-291.

Nanni, M.R. \& Dematte, J.A.M. (2006) Spectral reflectance methodology in comparison to traditional soil analysis. Soil Sci. Soc. Am. J, Vol.70, pp.393-407.

New York Times (2008) Tennessee ash flood larger than initial estimate, Published on December 26, 2008, URL: http://www.nytimes.com/2008/12/27/us/27sludge. html? $\_r=2 \mathcal{E} r e f=$ us (last date accessed: 1 July 2009).

Nyamangara, J. \& Mzezewa, J. (1999) The effect of long-term sewage sludge application on $\mathrm{Zn}, \mathrm{Cu}, \mathrm{Ni}$ and $\mathrm{Pb}$ levels in a clay loam soil under pasture grass in Zimbabwe. Agric. Ecosyst. Environ, Vol.73, pp.199-204.

Page, A.L.; Elseewi, A.A. \& Straughan, I.R. (1979) Physical and chemical properties of fly ash from coal-fired power plants with special reference to environmental impacts. Residue Reviews, Vol.71, pp.83-120.

Post, D.F.; Fimbres, A.; Matthias, A.D.; Sano, E.E.; Accioly, L.; Batchily, A.K. \& Ferreira, L.G. (2000) Predicting soil albedo from soil color and spectral reflectance data. Soil Sci. Soc. Am. J, Vol.64, pp.1027-1034.

Reeves, III J.B.; McCarty, G.W.; Mimmo, T. (2002) The potential of diffuse reflectance spectroscopy for the determination of carbon inventories in soil. Environ. Pollut. Vol.116, pp.S264-S277.

SAS Institute. SAS Software Version 9.1. Cary, NC: SAS Institute, Inc.; 2002-2003.

Shober, A.L. \& Sims, J.T. (2003) Phosphorus restrictions for land application of biosolids: current status and future trends. J. Environ. Qual, Vol.32, pp.1955-1964.

Singh, R.P. \& Agrawal, M. (2008) Potentail benefits and risks of land application of sewage sludge. Waste Management, Vol.28, pp.347-358.

Soil Survey Staff, Natural Resources Conservation Service, United States Department of Agriculture. Web Soil Survey. http:/ / websoilsurvey.nrcs.usda.gov. 2007.

Sommers, L.E. (1977) Chemical composition of sewage sludges and analysis of their potential use as fertilizers. J. Environ. Qual, Vol.6, pp.225-232.

Sridhar, B.B.M. \& Vincent, R.K. (2009) Mapping and estimation of phosphorus and copper concentrations in fly ash spill area using LANDSAT TM Images. Photogrammetric Engineering and Remote Sensing, Vol.75, Nb.9, pp.1030-1033.

Sridhar, B.B.M.; Vincent, R.K.; Witter, J.D. \& Spongberg, A.J. (2009) Mapping the total phosphorus concentration of biosolid amended surface soils using LANDSAT TM data. Science of Total Environment, Vol.47, pp.2894-2899.

Sullivan, D.G.; Shaw, J.N. \& Rickman, D. (2005) IKONOS imagery to estimate surface soil property variability in two Alabama physiographies. Soil Sci. Soc. Am. J, Vol.69, pp.1789-1798.

Tennessee Valley Authority (2009) Corrective Action Plan for the TVA Kingston Fossil Plant Ash Release, URL: http://www.tva.gov/kingston/cap/ TVA_Corrective _ Action_ Plan_Draft_D5.pdf(last date accessed: 1 July 2009).

Tetra Tech EM Inc. (2009) Final CERCLA emergency response report, Kingston fossil plant Fly ash response Harriman, Roane County, Tennessee Tetra Tech Inc. Soil and ash sampling results Kingston fossil fly ash response Harriman, Roane County, Tennessee, URL: http://www.epaosc.org/sites/4642/files/ erfinal reporttvakingston.pdf (last date accessed: 1 July 2009). 
U. S. Environmental Protection Agency. Standards for the use or disposal of sewage sludge. Office of Water, Washington D. C, 2002.

U. S. Environmental Protection Agency. Test methods for evaluating solid waste. Office of Solid Waste and Emergency Response, Washington D. C, 1998.

Udom, B.E.; Mbagwu, J.S.C.; Adesodun, J.K. \& Agbim, N.N. (2004) Distributions of zinc, copper, cadmium and lead in a tropical ultisol after long-term disposal of sewage sludge. Environ. Int. Vol.30, pp.467-470.

Varvel, G.E.; Schlemmer, M.R. \& Schepers, J.S. (1999) Relationship between spectral data from an aerial image and soil organic matter and phosphorus levels. Precision Agric, Vol.1, pp.291-300.

Vincent, R.K. (1997) Fundametals of geological and environmental remote sensing. Prentice Hall, Upper Saddle River, NJ.

Vincent, R.K. (2000) Forecasts of monthly averaged daily temperature highs in Bowling Green, Ohio from monthly sea surface temperature anomalies in Eastern Pacific ocean during the previous year. Photogramm. Eng. Remote Sens, Vol.66, pp.10011009.

Vincent, R.K.; Qin, X.; McKay, R.M.L.; Miner, J.; Czajkowski, K.; Savino, J. \& Bridgeman, T. (2004) Phycocyanin detection from LANDSAT TM data for mapping cyanobacterial blooms in Lake Erie. Remote Sens. of Environ, Vol.89, pp.381-392.

Wei, Q.F.; Lowery, B. \& Peterson, A.E. (1985) Effect of sludge application on physical properties of a silty clay loam soil. J. Environ. Qual, Vol.14, pp.178-180. 


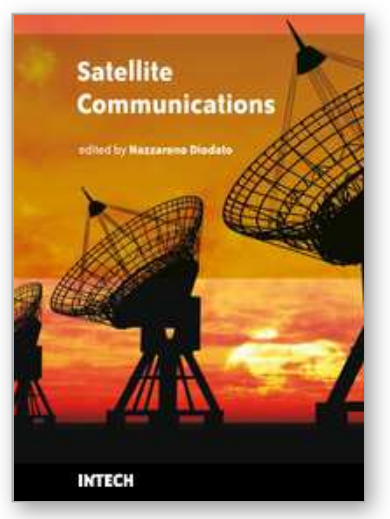

\author{
Satellite Communications \\ Edited by Nazzareno Diodato
}

ISBN 978-953-307-135-0

Hard cover, 530 pages

Publisher Sciyo

Published online 18, August, 2010

Published in print edition August, 2010

This study is motivated by the need to give the reader a broad view of the developments, key concepts, and technologies related to information society evolution, with a focus on the wireless communications and geoinformation technologies and their role in the environment. Giving perspective, it aims at assisting people active in the industry, the public sector, and Earth science fields as well, by providing a base for their continued work and thinking.

\title{
How to reference
}

In order to correctly reference this scholarly work, feel free to copy and paste the following:

Balaji Bhaskar Maruthi Sridhar and Robert K. Vincent (2010). Mapping and Estimation of Chemical Concentrations in Surface Soils using LANDSAT TM Satellite Imagery, Satellite Communications, Nazzareno Diodato (Ed.), ISBN: 978-953-307-135-0, InTech, Available from: http://www.intechopen.com/books/satellitecommunications/mapping-and-estimation-of-chemical-concentrations-in-surface-soils-using-landsat-tmsatellite-imager

\section{INTECH}

open science | open minds

\section{InTech Europe}

University Campus STeP Ri

Slavka Krautzeka 83/A

51000 Rijeka, Croatia

Phone: +385 (51) 770447

Fax: +385 (51) 686166

www.intechopen.com

\section{InTech China}

Unit 405, Office Block, Hotel Equatorial Shanghai

No.65, Yan An Road (West), Shanghai, 200040, China

中国上海市延安西路65号上海国际贵都大饭店办公楼 405 单元

Phone: +86-21-62489820

Fax: +86-21-62489821 
(C) 2010 The Author(s). Licensee IntechOpen. This chapter is distributed under the terms of the Creative Commons Attribution-NonCommercialShareAlike-3.0 License, which permits use, distribution and reproduction for non-commercial purposes, provided the original is properly cited and derivative works building on this content are distributed under the same license. 